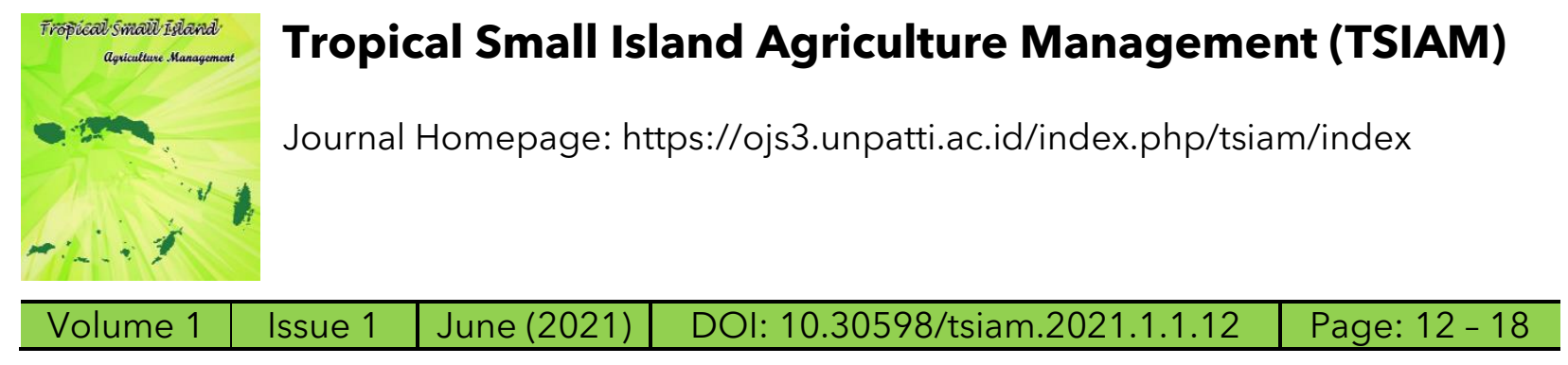

\title{
Physicochemical Characteristics of Black Bean Protein Concentrate Based on the Variation of Heating Time
}

\author{
Syane Palijama, Priscillia Picauly ${ }^{\star}$, Windarti \\ Department of Agricultural Product Technology, Faculty of Agriculture, Pattimura University, \\ Indonesia
}

*Email Corresponding Author: priscilliapicauly@gmail.com

\begin{abstract}
ART ICLE INFO
Keywords: Protein extraction; black beans; protein concentrate; heating time.

Received : 20 January 2021

Revised : 14 April 2021

Accepted : 20 June 2021

A B S T R A C T

One type of beans that can be used as a source of protein is the black bean (Phaseolus vulgaris. L); because it has a sufficiently high protein content of $16.6 \%$, it has the potential to be developed into protein concentrate. This study aimed to characterize the physicochemical characteristics of black bean protein concentrate based on heating time. An experiment was carried out and arranged in a Completely Randomized Design, with four levels of treatments, i.e. heating time of 15 minutes, 30 minutes, 45 minutes, and 60 minutes. The observed variables were yield, bulk density, water absorption, protein content, moisture content, and ash content. The results showed that the yield value was $7.66-12.11 \%$, bulk density $0.78-0.81 \mathrm{~g} / \mathrm{mL}$, water absorption $1.84-1.97 \%$, protein content $71.39-76.00 \%$, moisture content $11.85-12.94 \%$ and ash content $3.30-3.57 \%$.
\end{abstract}

\section{Introduction}

Beans Black bean is a local food source that has abundant protein, with various colours, varieties and shapes and has the potential to be developed to add variety and nutrients to various food products, especially protein. (Purnomo et al., 2015). In Indonesia, black beans have been cultivated and consumed for a long time, with different names for each region. One of the black beans producing areas in Southeast Sulawesi. The processing technique for black beans in this area is still simple. Usually, black beans are only used as a mixture of rice, vegetables, cakes and soup. While this food has a relatively complete nutritional content compared to other types of beans legumes. The protein content of black beans are classified as high, i.e. 16.6\% (TKPI, 2017). Lack of public knowledge has caused that black bean is still very limited in processing and consumed only as a vegetable. For this reason, it is necessary to diversify black bean food, one of which is as a protein concentrate. Protein concentrate is a 
product containing $70 \%$ protein and is widely used in bakery products, processed meat, vegetarian food, and dairy products. Until now, the need for protein concentrate has been met mainly by foreign production. Principally, making protein concentrate is extracting protein from non-protein components. Protein concentrate is made by removing non-protein components such as fat, carbohydrates, minerals, and water so that the product protein content is higher than the original raw material. An extraction process can do the removal of non-protein components in the manufacture of protein concentrate. Protein concentrate can be extracted using alkaline after degrading the fat, then the supernatant is centrifuged, and the $\mathrm{pH}$ of the solution is adjusted according to the isoelectric point to obtain protein deposits (Zhao et al., 2012). The method used in extraction can affect the composition of the protein concentrate (Tiwari \& Singh, 2012). (Adhibuana, Hintono and Pramon, 2018) used an extraction method with a heating time of 30 minutes to extract protein concentrate from cowpeas. Meanwhile, according to (Purwitasari, Hendrawan and Yulianingsih, 2014) to extract the protein concentrate from komak bean, a heating time of 60 minutes can be used. There are differences and the effect of heating time in protein concentrate extraction. This paper aims to characterize the physicochemical characteristics of black bean protein concentrates based on variations in heating time.

\section{Materials and Methods}

\section{Materials}

The materials used in this study were black beans obtained from Banua Village, West Siompu District, South Buton Regency, Southeastern Sulawesi. The materials used for the protein concentrate extraction process were distilled water, and 70\% ethanol (Merck, Germany), $1 \mathrm{~N} \mathrm{NaOH}$, and $1 \mathrm{~N} \mathrm{HCL}$ (Merck, Germany).

\section{Methods}

\section{Black Bean Protein Concentrate Extraction}

Method of (Adhibuana, Hintono and Pramono, 2018). Black beans were soaked in water for 7 hours, and the skin was peeled. $250 \mathrm{~g}$ of beans were crushed using a blender filled with distilled water with a ratio of distilled water to beans (3:1). The crushed beans were filtered, and the filtrate was taken. The filtrate was added with $1 \mathrm{~N} \mathrm{NaOH}$ until it reached a pH of 9.5. The filtrate was heated at $55^{\circ} \mathrm{C}$ for 15 minutes, 30 minutes, 45 minutes, and 60 minutes. The filtrate was cooled at room temperature and centrifuged at $2000 \mathrm{rpm}$ for 10 minutes. The supernatant that resulted from the centrifugation was given the addition of $1 \mathrm{~N} \mathrm{HCL}$ until the $\mathrm{pH}$ of the supernatant reached 4.5 and was centrifuged at $2000 \mathrm{rpm}$ for 10 minutes. The centrifuged precipitate was mixed with $70 \%$ ethanol solution with a volume of 3 times the 
weight of the precipitate. The solution was centrifuged at $2000 \mathrm{rpm}$ for 10 minutes. The precipitate was dried using an oven at $50{ }^{\circ} \mathrm{C}$ for 18 hours until dry and turned into crystals.

\section{Chemical Analysis}

Moisture was determined according to the methods of AOAC (2000), Micro-Kjeldahl determined the protein according to the methods of (AOAC, 2000), and ash was determined according to the method of AOAC (2000).

\section{Yield}

The yield calculation was carried out by weighing the protein concentration of dried black beans produced then divided by the weight of the dried raw material (Dunford, 2012).

\section{Bulk Density}

Bulk density was determined following (Okezie \& Bello., 1988). The sample was put into a measuring cup of $10 \mathrm{ml}$ whose weight is known. The measuring cup that has contained the sample was tapped against the table until there was no more cavity when the sample was adjusted to be $10 \mathrm{ml}$. The measuring cup containing the sample was then weighed. The bulk density $(\mathrm{g} / \mathrm{mL})$ was calculated by dividing the weight of the sample by its volume $(10 \mathrm{~mL})$.

\section{Water Absorption}

Water absorption was determined following Sosulski, Garrat, \& Slinkard (1976). A total of $1 \mathrm{~g}$ of sample and $10 \mathrm{ml}$ of distilled water were put into a test tube and vortexed for 2 minutes. The mixture was then allowed to stand for 30 minutes at room temperature and was centrifuged at $3000 \mathrm{rpm}$ for 30 minutes. The filtrate was poured into a $10 \mathrm{ml}$ measuring cup carefully, and the volume was measured. Water absorption was determined from $10 \mathrm{~mL}$ of filtrate, reducing the filtrate volume and dividing by the weight of the sample.

\section{Experimental Design and Statistical}

This study used a completely randomized design with four levels of heating time for the extraction of black bean protein concentrate, namely $15,30,45$, and 60 minutes. Data were analyzed using Minitab software version 17 (Minitab, LLC , Pennsylvania, USA) and followed by Tukey's test at the $95 \%$ level $(\alpha=0.05)$ to determine the differences between these treatments. 


\section{Results and Discussion}

Yield

The yield analysis of black bean protein concentrate was $7.66-12.11 \%$. Table 1 shows that the black bean protein concentrate in the 60-minute heating treatment had the highest yield, $12.11 \%$. The high yield was influenced by the protein solubility of black bean protein concentrate. The research results by Pratiwi, Yusasrini, \& Putra, (2018) showed that the higher the protein solubility, the higher the yield of the product. Factors that influence protein solubility include molecular weight, amino acid composition, $\mathrm{pH}$, type of solvent, processing condition, and temperature. The heating process for a long time can cause a change in protein structure. The results of the research by Pratiwi, Yusasrini, \& Putra (2018), the yield produced in the manufacture of protein concentrate from gude beans ranged from $12.87 \%$ to $17.29 \%$, while the yield of cowpea protein concentrate produced using $70 \%$ ethanol was $4.85 \%$ (Adhibuana, Hintono and Pramono, 2018) and the yield of red bean protein concentrate is $13.69 \%$ (Piñuel et al., 2019).

Table. 1. Physicochemical Characteristics of Black Bean Protein Concentrate

\begin{tabular}{ccccccc}
\hline $\begin{array}{c}\text { Heating } \\
\text { times } \\
\text { (minutes) }\end{array}$ & Yield (\%) & $\begin{array}{c}\text { Bulk density } \\
(\mathrm{g} / \mathrm{mL})\end{array}$ & $\begin{array}{c}\text { Water } \\
\text { absorption } \\
(\%)\end{array}$ & $\begin{array}{c}\text { Protein } \\
\text { content } \\
(\%)\end{array}$ & $\begin{array}{c}\text { Moisture } \\
\text { content } \\
(\%)\end{array}$ & $\begin{array}{c}\text { Ash content } \\
(\%)\end{array}$ \\
\hline 15 & $7.66 \mathrm{~d} \pm 0.07$ & $0.78 \mathrm{~b} \pm 0.02$ & $1.85 \mathrm{a} \pm 0.02$ & $73.28 \mathrm{~b} \pm 0.19$ & $11.85 \mathrm{~b} \pm 0.03$ & $3.44 \mathrm{a} \pm 0.12$ \\
30 & $11.31 \mathrm{~b} \pm 0.07$ & $0.81 \mathrm{a} \pm 0.05$ & $1.97 \mathrm{a} \pm 0.02$ & $76.00 \mathrm{a} \pm 0.20$ & $12.76 \mathrm{a} \pm 0.21$ & $3.57 \mathrm{a} \pm 0.09$ \\
45 & $9.70 \mathrm{c} \pm 0.14$ & $0.81 \mathrm{a} \pm 0.02$ & $1.84 \mathrm{a} \pm 0.01$ & $73.63 \mathrm{~b} \pm 0.03$ & $12.75 \mathrm{a} \pm 0.08$ & $3.47 \mathrm{a} \pm 0.20$ \\
60 & $12.11 \mathrm{a} \pm 0.07$ & $0.81 \mathrm{a} \pm 0.08$ & $1.85 \mathrm{a} \pm 0.03$ & $71.39 \mathrm{c} \pm 0.11$ & $12.94 \mathrm{a} \pm 0.09$ & $3.30 \mathrm{a} \pm 0.19$ \\
\hline \multicolumn{7}{l}{ Different letters in the same column mean significantly different $(\mathrm{p}<0.05)$}
\end{tabular}

\section{Bulk Density}

The analysis results showed that the average density value of black bean concentrate Kamba ranged from $0.779-0.816 \%$. Table 1 shows the black bean protein concentrate with the heating treatment of 30,45 , and 60 minutes had the highest Kamba density value, namely 0.81 $\mathrm{g} / \mathrm{mL}$. Kamba density is influenced by the material and water content (Purwitasari, Hendrawan and Yulianingsih, 2014). The material size of the particles indicates the porosity of the material, namely the number of cavities between the particles of the material. The high water content causes the particles in the protein concentrate to become heavier so that the volume in the particle cavity becomes smaller because the particles formed are more significant and cause the density value of the cage to be more significant. The research results by (Purwitasari, Hendrawan and Yulianingsih, 2014) showed that the density of protein concentrate Kamba in comak beans ranged from $0.54-0.59 \mathrm{~g} / \mathrm{mL}$. 


\section{Water Absorption}

The analysis results showed that the average value of black bean concentrate water absorption ranged from 1.85 to $1.97 \%$. Table 1 shows the black bean protein concentrate with a heating time of 30 minutes has a water absorption capacity of $1.97 \%$, but not significantly different from other treatments. The data from the research result showed an increased water absorption in the 30 minutes heating treatment, then decreased in line with the increasing heating time. This is thought to have occurred by stretching the starch structure found in black beans so that they can absorb water. The size of the starch granules, which become more swollen due to heating, also can increase water absorption (Jumanah, Windrati and Maryanto, 2018). Decreased water absorption on heating treatment 45 and 60 minutes, thought to be caused by damage to most of the starch so that the ability to absorb water from starch decreased. The results of the research by Pratiwi, Yusasrini, \& Putra (2018), showed that the water absorption capacity of 'gude' bean protein concentrate was $1.61 \%$, and the water absorption capacity of 'gude' bean protein concentrate was $2.00 \mathrm{~g} / \mathrm{g}$ (Pazmiño, Vásquez and Carrillo, 2018).

\section{Protein Content}

The protein analysis results showed that the average protein content of black bean concentrate ranged from $73.28-76.00 \%$. Table 1 shows that the black bean protein concentrate in the 30-minute heating treatment was the optimum extraction time so that the optimum protein content of black bean protein concentrate was obtained with a value of $76.00 \%$. Heating in an alkaline atmosphere during the extraction process will result in high protein solubility. According to (Pazmiño, Vásquez and Carrillo, 2018)), the higher the degree of acidity of the protein solution from its isoelectric point $(\mathrm{pH} 4.5)$, the solubility will increase. Protein in food has complex bonds with other components such as carbohydrates, fats, minerals, and water. However, after removing the non-protein components, the protein is free so that it is easier to measure during analysis. The protein content in the protein concentration increases because some of the carbohydrates have dissolved in ethanol. Decreased protein contents on heating treatment 45 and 60 minutes were due to changes in the structure of the protein molecule. The results of the research by (Piñuel et al., 2019) showed that red bean protein concentrate had a protein content of $65.53 \%$, whereas (Zar Oo, Linn Ko and Soe Than, 2017) stated that the green bean protein concentrate protein was $51.37 \%$.

\section{Moisture Content}

The results of the analysis of black bean protein concentrate ranged from 11.85 $12.94 \%$. Table 1 shows that the protein concentrate with a heating time of 60 minutes showed the highest average value of moisture content $12.94 \%$. The resulting moisture content could be 
affected by the yield of protein concentrate. By using interpolation, the water content was directly proportional to the yield of protein concentrate. The higher the yield of protein concentrate, the higher the moisture content produced. This is in line with the research results on the yield of black bean protein concentrate, directly proportional to the moisture content. The results of the research by (MMA et al., 2011)) showed that the moisture content of the bamboo bean protein concentrate was $8.92 \%$, and the moisture content of the green bean protein concentrate was $8.54 \%$ (Zar Oo, Linn Ko and Soe Than, 2017).

\section{Ash Content}

The analysis results showed that the average value of black bean protein concentrate ash ranged from $3.30-3.58 \%$. The research by (MMA et al., 2011) showed that the ash content of the Bambara bean protein concentrate was $3.86 \%$, while the ash content of the green bean protein concentrate was 1.94\% (Zar Oo, Linn Ko and Soe Than, 2017). The results of research by (do Evangelho et al., 2016) showed that the ash content of black beans was $4.3 \%$. So it can be seen that there is a decrease in the ash content after black beans are extracted into protein concentrate. The decrease in ash content is due to the minerals in black beans that dissolve in ethanol in the protein concentrate extraction process. Based on polarity and solubility, polar compounds will dissolve easily in polar solvents, while non-polar compounds will dissolve easily in non-polar solvents. Ethanol can be used to purify protein extraction because ethanol can dissolve the remaining non-protein components in the protein concentrate, such as ash material, in the extraction results.

\section{Conclusion}

Based on the results of the study, it was concluded that the best heating time for protein concentrate extraction from black bean was 30 minutes, resulting in a yield of $11,31 \%$, bulk density $0,814 \mathrm{~g} / \mathrm{mL}$, water absorption $1,97 \%$, protein content $76 \%$, moisture content $12,76 \%$, and ash content $3,57 \%$.

\section{References}

Adhibuana, M. J., Hintono, A. and Pramono, Y. B. (2018). 'Rendemen dan kadar protein konsentrat protein kacang tunggak (Vigna unguiculata) yang diekstraksi dengan larutan etanol dan aseton dengan konsentrasi berbeda', Jurnal Teknologi Pangan, 2(1), pp. 1720.

Association of Analytical Communities International. Official Methods of Analysis of AOAC. 2000. 17th ed. Gaithersburg, MD, USA: AOAC International.

do Evangelho, J. A. Berrios J. de J., Pinto V. Z., Antunes M. D., Vanier N. L., Zavarese E. da R. (2016). 'Antioxidant activity of black bean (Phaseolus vulgaris L.) protein hydrolysates', Food Science and Technology, 36, pp. 23-27. doi: 10.1590/1678457X.0047. 
Dunford N. T. (2012). Food and Industrial Bioproducts and Bioprocessing. Wiley-Blackwell, U.S.A

Jumanah, J., Windrati, W. S. and Maryanto, M. (2018) 'Karakterisasi sifat fisik, kimia dan sensoris bihun berbahan tepung komposit ganyong (Canna edulis) dan kacang hijau (Vigna radiata)', Jurnal Agroteknologi, 11(02), pp. 128. doi: 10.19184/j-agt.v11i02.6517.

MMA, M. Minka S. R., Mbome I. L., Etoa, F. X. (2011). Nutritional potential of bambara bean protein concentrate, Parkistan Journal of Nutrition, 10(2), pp. 112-119.

Okezie B. O \& Bello A. B. (1988). Physicochemical and functional properties of winged bean flour and isolate compared with soy isolate. Journal Food Science, 53, 450-454. https://doi.org/10.1111/j.1365-2621.1988.tb07728.

Pazmiño, A., Vásquez, G. and Carrillo, W. (2018) 'Pigeon pea protein concentrate (Cajanus cajan) seeds grown in Ecuador functional properties', Asian Journal of Pharmaceutical and Clinical Research, 11(6), pp. 430-435. doi: 10.22159/ajpcr.2018.v11i6.24966.

Piñuel, L. Vilcacundo E., Boeri P., Barrio D. A., Morales D., Pinto A., Moran R., Samaniego I., Carrilo W. (2019) 'Extraction of protein concentrate from red bean (Phaseolus vulgaris L.): Antioxidant activity and inhibition of lipid peroxidation', Journal of Applied Pharmaceutical Science, 9(9), pp. 045-058. doi: 10.7324/JAPS.2019.90804.

Pratiwi H., Yusasrini N. L. A., Putra I. N. K. (2018). Pengaruh pH ekstraksi terhadap rendemen, sifat fisiko kimia dan fungsional konsentrat protein kacang gude (Cajanuscajan (L). Mill. sp). Jurnal ITEPA, 7(1), 1-11.

Purnomo, E. H. Ginanjar A. N., Kusnandar F., Andriani C. (2015) 'Karakterisasi sifat fisikokimia tepung kacang hitam (Phaseolus vulgaris) dan aplikasinya pada brownies panggang', Jurnal Mutu Pangan, 2(1), pp. 26-33.

Purwitasari, A., Hendrawan, Y. and Yulianingsih, R. (2014) 'Pengaruh suhu dan waktu ekstraksi terhadap sifat fisik kimia dalam pembuatan konsentrat protein kacang komak (Lablab purpureus (L.) sweet) ', Jurnal Bioproses Komoditas Tropis, 2(1), pp. 42-53. Available at: https://jbkt.ub.ac.id/index.php/jbkt/article/view/135.

Sosulski F. W., Garatt M. O., Slinkard A. E. (1976). Functional properties of ten legume flours. Intern Journal Food Science Technology, 9, 66-69.

Tabel Komposisi Pangan Indonesia (TKPI). (2017). Kementerian Kesehatan Republik Indonesia. Jakarta. http://www.panganku.org/id-ID/berita/20. (accessed 16 Februari 2021).

Tiwari, K., \& N. Singh. (2012). Pulse Chemistry and Technology. RSC Publishing, U. K. https://pubs.rsc.org/en/content/ebook/978-1-84973-331-1.

Zar Oo, Z., Linn Ko, T. and Soe Than, S. (2017) 'Physico-chemical properties of extracted Mung Bean protein concentrate', American Journal of Food Science and Technology, 5(6), pp. 265-269. doi: 10.12691/ajfst-5-6-7.

Zhao, J. Liu D., Chen F., and Liu, G (2012) 'Functional properties of sesame seed protein prepared by two different methods, Journal of Chemical Society of Pakistan 1', 34(5), 1101-1106. 